\title{
Effect of reduced spray programmes on incidences of apple scab, powdery mildew and codling moth damage in environmentally freindly apple production systems
}

\author{
Holb, I.J., Fazekas M., Abonyi F., Lakatos P., Thurzó S., Nyéki J., Szabó Z., Kruppa J. \& Balla B. \\ Centre of Agricultural Sciences, University of Debrecen 138 Böszörményi St., 4032 Debrecen, Hungary
}

\begin{abstract}
Summary: Still a large amount of pesticides and spary applications are used in environmentally friendly fruit production systems; therefore, the aim of our study was first to test the in vitro effeicacy of some fungicides against a key apple disease (apple scab), and secondly to evaulate the effectiveness of reduced spray programmes against apple scab, powdery mildew and coding moth in integrated and organic apple orchards. In vitro efficacy of 7 fungicides (Champion 50 WP, Kocide 2000, Nordox 75 WG, Olajos rézkén, Kumulus S, Rézkén, Rézoxiklorid) and another 6 fungicides (Score 25 EC, Efuzin 500 SC, Systane, Folicur Solo, Zato Plusz, Rovral) approved in organic and integrated production systems, respectively, were tested against apple scab. Altogether four spray programmes were performed i) standard integrated: sprays followed by forecasting systems during the season, ii) reduced integrated: sprays followed by forecasting systems but only $75 \%$ of the spray numbers used during the season-long spray programme, iii) standard oragnic: sprays applied every 7-14 days during the season and iv) reduced organic: $60 \%$ of the spray numbers used during the season-long spray programme. In vitro results showed that fungicides (with active ingredients of copper and sulphur) applied in organic production showed relatively high percent growth capacity of the apple scab fungus. Rézkén showed the highest and Kumilus $\mathrm{S}$ the lowest efficacy against apple scab. Fungicides applied in integrated production showed relatively low percent growth capacity of the apple scab fungus. Score 25 EC showed the highest and Rovral the lowest efficacy against apple scab. Field study showed that reduced spray programmes did not increase significantly scab incidence in the integrated field. However, scab incidence increased significanly (above 30\%) in the reduced spray programme for the organic orchard. Mildew incidence was low (below 5\%) in both integrated and organic spray programmes. Mildew incidence on both shoots and fruits increased significanly in the reduced spray programme for the organic orchard. Incidence of codling moth damage was affected the most by standard vs. reduced spray programmes. Though incidence remained below $10 \%$ in the integrated plots, the incidence was significantly higher in the reduced spray programme compared to the standard programme. Similar results were obtained for organic spary programmes, but the incidence was 10 times higher and the differences among the two programmes were larger.
\end{abstract}

Key words: apple, apple scab, powdery mildew, codling moth, Podosphaera leucotricha, Cydia pomonella, Venturia inaequalis, organic, integrated

\section{Introduction}

In the 1960s, after not more than a decade of the widespread use of the first non-phytotoxic and highly effective synthetic pesticides in conventional agriculture, it became obvious that they have several limitations and serious harmful effects on the environment and on human health. This prompted a serious need for a more environmentally benign view in the practice of agriculture and particularly in plant protection which strengthened the concept of environmentally friendly approach for agriculture. By the end of the 1970s after a long period of development (started long before the introduction of the above-mentioned synthetic pesticides), environmentally friendly production systems emerged in apple production and later two directions became known worldwide: the integrated and organic production systems (e.g. Sansavini, 1990, 1997; Sansavini \& Wollesen, 1992; Bellon et al., 2001; Lancon et al., 2007).
By now, the rules and several tools for fungal disease and pest management are well-defined and most of them are successfully implemented for the two environmentally friendly productions systems in apple (e.g. Anon., 1989; Cross \& Dickler, 1994; Zalom, 1993; Holb, 2005). Disease and pest management practices in integrated and organic apple production differ markedly from those in conventional production. Synthetic products are restricted in integrated and banned in organic apple production. In organic apple growing, only natural products such as compost, soluble rock powder, sulphur and copper compounds, fungicidal and botanical soaps, traps and biological methods are permitted against fungal diseases and pests according to IFOAM (International Federation of Organic Agriculture Movements) standards (e.g. Anon., 2000; Holb et al., 2005), while many synthetic pesticides can be used in conventional apple production.

One of the imporant aims of environmentally freindly production systems are to reduce number of pesticides and 
spray applications (e.g. Zalom, 1993; Anon., 2000; Holb, 2005, 2008ab). However, still a large amount of pesticides and spary applications are used in environmentally friendly fruit production systems; therefore, the aim of our study was first to test the in vitro effeicacy of some fungicides against a key apple disease (apple scab), and secondly to evaulate the effectiveness of reduced spray programmes against apple scab, powdery mildew and coding moth in integrated and organic apple orchards.

\section{Materials and methods}

\section{Laboratory study}

In vitro efficacy of 7 fungicides (Champion $50 \mathrm{WP}$, Kocide 2000, Nordox 75 WG, Olajos rézkén, Kumulus S, Rézkén, Rézoxiklorid) and another 6 fungicides (Score 25 EC, Efuzin 500 SC, Systane, Folicur Solo, Zato Plusz, Rovral) approved in organic and integrated production systems, respectively, were tested against apple scab. Fungicides were admended in PDA media. Two dosages were used: i) $1 \times$ dosage recommended by the manufacturer and ii) $0.5 \times$ dosage of the recommended dosage. Conidia of Spilocaea pomi (Venturia inaequalis) perpared from infected leaves were placed on Petri dishes admended with fungicide. Dishes were incubated for 24 hours at near saturation humidity at $18{ }^{\circ} \mathrm{C}$. Germination of conidia was evaluated after 24 hours incubation and percent growth capacity (GC) of the fungus was evaluated as $\mathrm{GC}=\mathrm{X} / \mathrm{Y} \times 100$, where ' $\mathrm{X}$ ' is percent germination of conidia in a fungicide plate, and ' $\mathrm{Y}$ ' is the percent germination of conidia in control plate. Differences among fungicides were tested by ANOVA at $\mathrm{P}=0.05$ level using LSD test.

\section{Field study}

Field study for reduced fungicide spray programmes was performed in an integrated and an organic apple orchard at Eperjeske. The orchard was established in 1996. The two production systems were applied: one following the Hungarian IFP (integrated fruit production) guidelines; and the second following the Hungarian organic production guidelines. Each of the two fields consisted of 40 rows with a distance between rows of $4 \mathrm{~m}$, and between trees within a row of $1.5 \mathrm{~m}$. All trees were on M.26 rootstocks and pruned to a spindle shape. The main cultivars of the orchards were Prima, Jonagold, Mutsu, Jonathan and Idared. The experiment was done on cultivar Idared. The applied fungicides in the organic spray programmes were: Champion 50 WP, Kocide 2000, Nordox 75 WG, Olajos rézkén, Kumulus S, Rézkén, Rézoxiklorid. The applied fungicides in the integrated spray programmes were Score 25 EC, Efuzin 500 SC, Systane, Folicur Solo, Zato Plusz.

Altogether four spray programmes were performed two for the integrated and another two for the organic fields in 2009. The two integrated spray programmes were: i) standard: sprays followed by forecasting systems during the season (METOS agrometeorological station and codling moth pheromone trapping), ii) reduced: sprays followed by forecasting systems but only $75 \%$ of the spray numbers used during the season-long spray programme. The two organic spray programmes were: i) standard: sprays applied every 7-14 days during the season and ii) reduced: $60 \%$ of the spray numbers used during the season-long spray programme.

At the end of August, incidence of apple scab on leaves and fruits on 5 trees were assessed for each treatments. 50 leaves and 50 fruits per tree were selected randomly and counted for scab symptoms. At the same day, incidence of powdery mildew on shoots and fruits on 5 trees were assessed for each treatments. 20 shoots and 50 fruits per tree were selected randomly and counted for mildew symptoms. Incidence of coding moth damage was assessed on the same 5 trees on 50 fruits as for powdery mildew. Differences among spray programmes of integrated and organic were tested separatelly. Statistaics were performed by ANOVA at $\mathrm{P}=0.05$ level using LSD test.

\section{Results and discussion}

\section{In vitro study on fungicide efficacy against apple scab}

Fungicides (with active ingredients of copper and sulphur) applied at $1 \times$ dosage recommended by the manufacturer in organic production showed relatively high percent growth capacity of the apple scab fungus (25-55\%) (Figure 1). Especially sulphur had low in vitro effeciacy against apple scab. Rézkén showed the highest and Kumilus $S$ the lowest efficacy against apple scab.

Fungicides applied at $1 \times$ dosage recommended by the manufacturer in integrated production showed relatively low percent growth capacity of the apple scab fungus (2-12\%) (Figure 2). Score 25 EC showed the highest and Rovral the lowest efficacy against apple scab.

Fungicides (with active ingredients of copper and sulphur) applied at $0.5 \times$ dosage recommended by the

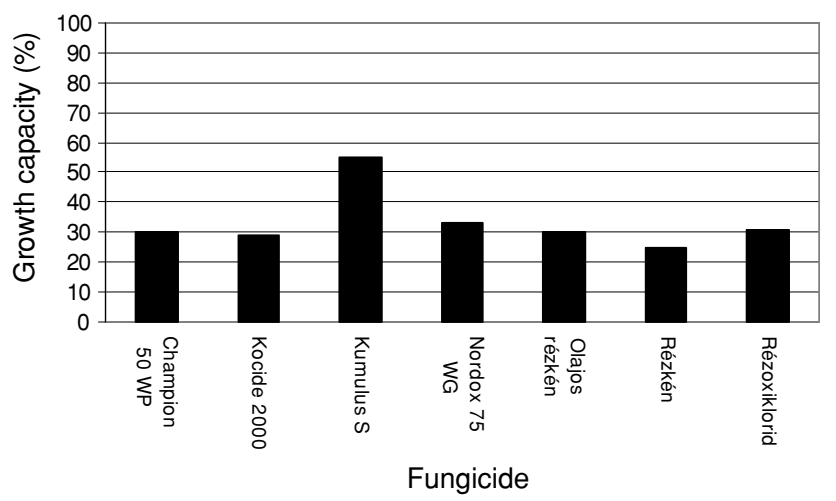

Figure 1. Percent growth capacity of Spilocaea pomi for 7 fungicides (organically approved) admended on PDA plates at $1 \times$ dosage recommended by the manufacturer $\left(\mathrm{LSD}_{0.05}=5.8\right)$ 


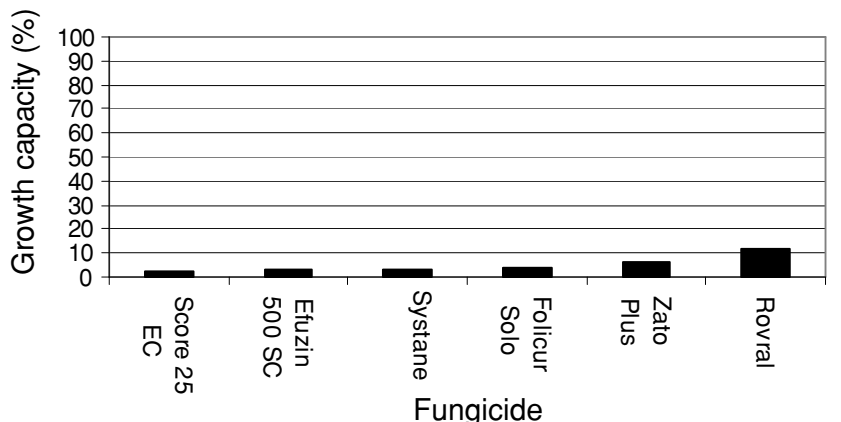

Figure 2. Percent growth capacity of Spilocaea pomi for 6 fungicides (approved in integrated production) admended on PDA plates at $1 \times$ dosage recommended by the manufacturer $\left(\operatorname{LSD}_{0.0} 5=2.4\right)$.

manufacturer in organic production showed relatively high percent growth capacity of the apple scab fungus (46-80\%) (Figure 3). Again sulphur had very low in vitro effeciacy against apple scab. Again, Rézkén showed the highest and Kumilus $\mathrm{S}$ the lowest efficacy against apple scab.

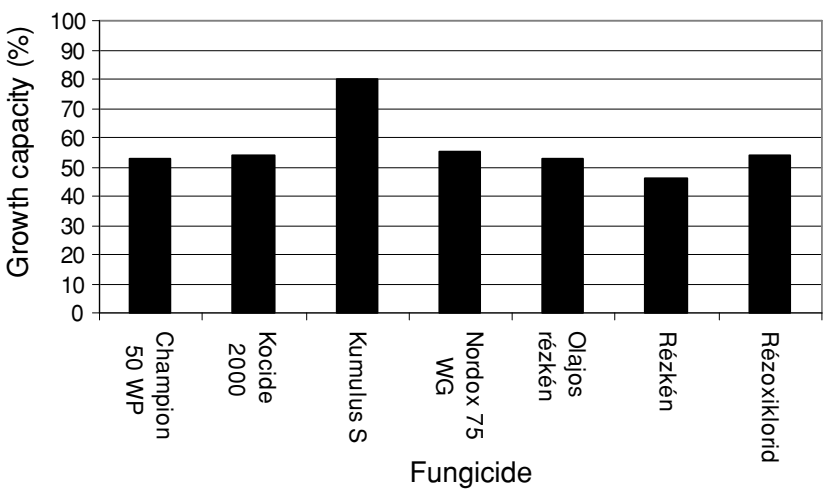

Figure 3. Percent growth capacity of Spilocaea pomi for 7 fungicides (organically approved) admended on PDA plates at $0.5 \times$ dosage recommended by the manufacturer $\left(\mathrm{LSD}_{0.05}=9.3\right)$.

Fungicides applied at $0.5 \mathrm{x}$ dosage recommended by the manufacturer in integrated production showed relatively low percent growth capacity of the apple scab fungus (2-12\%) (Figure 4). Again, Score 25 EC showed the highest and Rovral the lowest efficacy against apple scab.

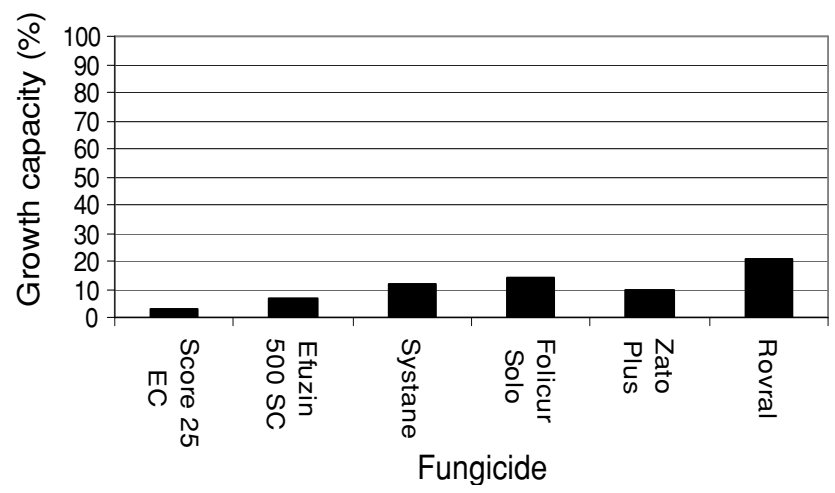

Figure 4. Percent growth capacity of Spilocaea pomi for 6 fungicides (approved in integrated production) admended on PDA plates at $0.5 \times$ dosage recommended by the manufacturer $\left(\mathrm{LSD}_{0.05}=5.6\right)$.

\section{Reduced spray programmes in integrated and organic apple orchards}

Scab incidence did not incerased above $10 \%$ in the integrated orchards; however, scab incidence was above $20 \%$ in the organic fields (Figure 5). Reduced spray programme did not increase significantly scab incidence in the integrated field. However, scab incidence increased significanly (above $30 \%$ ) in the reduced spray programme for the organic orchard.

Mildew incidence was low (below $5 \%$ ) in both integrated and organic spray programmes (Figure 6). Powery mildew incidence was above $20 \%$ in the organic fields. Mildew incidence on both shoots and fruits increased significanly in the reduced spray programme for the organic orchard.

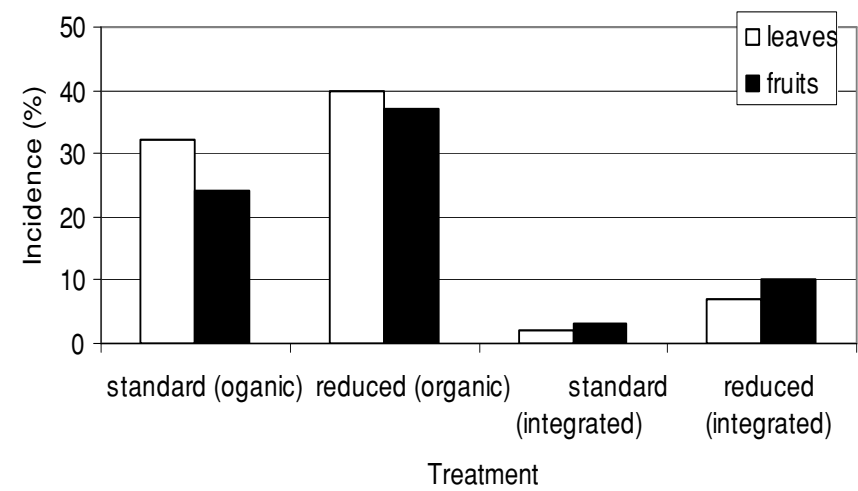

Figure 5. Efficacy of standard and reduced spray programmes on apple scab on leaf and fruit incidences in integrated and organic apple orchards $\left(\mathrm{LSD}_{0.05}=4.8\right.$ - integrated; $\mathrm{LSD}_{0.05}=7.6$ - organic)

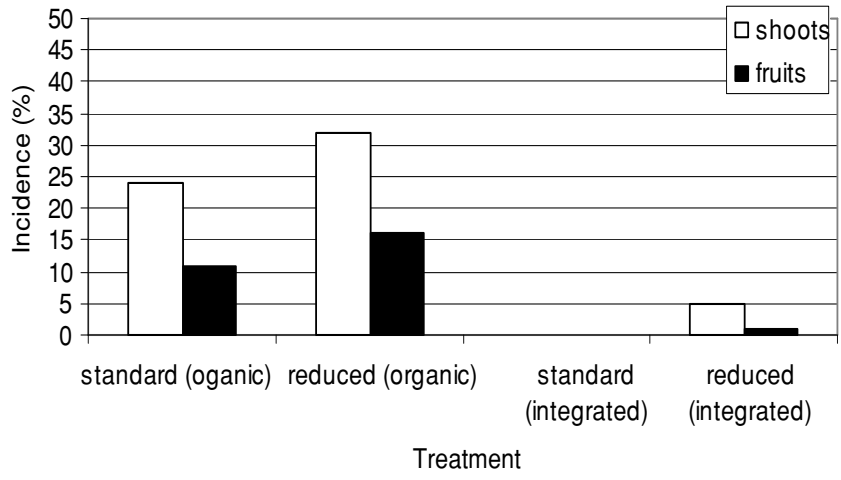

Figure 6. Efficacy of standard and reduced spray programmes on powdery mildew on shoot and fruit incidences in integrated and organic apple orchards $\left(\mathrm{LSD}_{0.05}=3.2\right.$ - integrated; $\mathrm{LSD}_{0.05}=9.4$ - organic $)$

Incidence of codling moth damage was affected the most by standard vs. reduced spray programmes (Figure 7). Though incidence remained below $10 \%$ in the integrated plots, the incidence was significantly higher in the reduced spray programme compared to the standard programme. Similar results were obtained for organic spary programmes, but the incidence was 10 times higher and the differences among the two programmes were larger. 


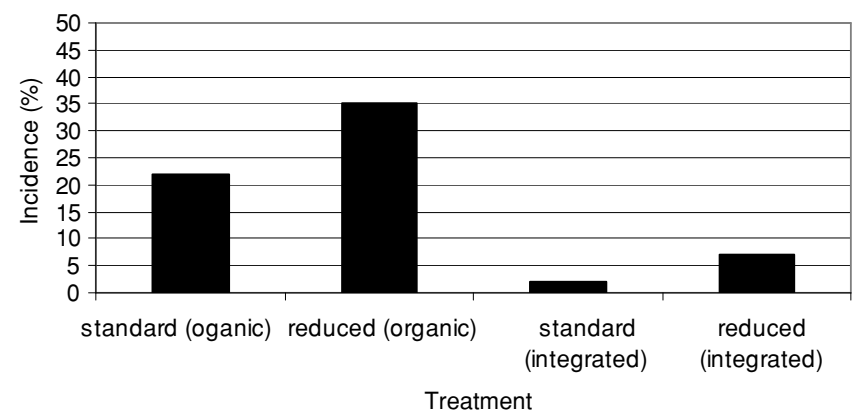

Figure 7. Efficacy of standard and reduced spray programmes on incidence of codling moth damage on fruit in integrated and organic apple orchards $\left(\mathrm{LSD}_{0.05}=3.7\right.$ - integrated; $\mathrm{LSD}_{0.05}=10.4$ - organic $)$

\section{Acknowledgements}

The study was supported by the NKTH programme (OM00227/2008) and by the research programme of OTKA (K 78399) as well as by a János Bolyai Research Fellowship.

\section{References}

Anonymous (1989): Basic Standards for Organic Agriculture, Tholey-Theley Press, New York, USA.

Anonymous (2000): IFOAM Basic Standards for Organic Production and Processing, Tholey-Theley Press, New York, USA.

Bellon S., Lescourret F. \& Calmet J.P. (2001): Characterisation of apple orchard management systems in a French Mediterranean Vulnerable Zone, Agronomie, 21: 200-213.
Cross J.V. \& Dickler E. (1994): Guidelines for integrated production of pome fruits in Europe. Technical guideline III, IOBC/WPRS Bulletin, 17 (9): 1-8.

Holb I.J. (2005): Effect of pruning on apple scab in organic apple production, Plant Dis., 89: 611-618.

Holb I.J. (2008a): Monitoring aerial dispersal of Monilinia fructigena conidia in relation to brown rot development in integrated and organic apple orchards, Eur. J. Plant Pathol., 120: 397-408.

Holb I.J. (2008b): Timing of first and final sprays against apple scab combined with leaf removal and pruning in organic apple production, Crop Prot., 27: 814-822.

Holb I.J., Heijne B., Withagen J.C.M., Gáll J.M. \& Jeger M.J. (2005b): Analysis of summer epidemic progress of apple scab in different apple production systems in the Netherlands and Hungary, Phytopathology, 95: 1001-1020.

Lancon J., Wery J., Rapidel B., Angokaye M., Gérardeaux E., Gaborel C., Ballo D. \& Fadegnon, B. (2007): An improved methodology for integrated crop management systems, Agron. Sustain. Dev. 27.

Sansavini S. (1990): Integrated fruit growing in Europe, HortScience, 25: 842-846.

Sansavini S. (1997): Integrated fruit production in Europe: research and strategies for a sustainable industry, Scient. Hortic., 68: 25-36.

Sansavini S. \& Wollesen J. (1992): The organic farming movement in Europe, Hortic. Technol., 2: 276-281.

Zalom F.G. (1993): Reorganizing to facilitate the development and use of integrated pest management, Agric. Ecosyst. Environ., 46: 245-256. 